DOI https://doi.org/10.30525/978-9934-26-000-1-30

\title{
ТЕНДЕНЦІЇ ВІДОБРАЖЕННЯ СОЦІАЛЬНО-ЕКОНОМІЧНОЇ ТЕМИ «ЖИТЛО/НЕРУХОМІСТЬ» В УКРАЇНСЬКИХ ДІЛОВИХ ОНЛАЙН-МЕДІА (НА ПРИКЛАДІ ВИДАННЯ «ТНЕ РАGЕ»)
}

\author{
Нікитенко В. М. \\ аспірантка \\ Інститут журналістики Київського національного університету \\ імені Тараса Шевченка \\ м. Київ, Украӥна
}

Через надмірний інформаційний шум тема житла в Україні в останні роки перетворилася на неприступного монстра. 3 одного боку, людину лякають категорії економічні - вартість квадратного метра, платіжки за комунальні послуги, маржа при будівництві тощо. Ними часто спекулюють забудовники, PR-фахівці будівельного сектору і політики. 3 іншого боку, в основі сфери житла - людина як кінцевий споживач продукту сфери нерухомості, а також комфортне середовище проживання, добробут і безпека. Саме тому першочергове завдання цього дослідження полягає у грунтовому й комплексному вивченні особливостей відображення соціально-економічної теми «житло/нерухомість» 3 урахуванням іiї бінарної природи у ділових онлайн-медіа України. Визначити роль соціальних і економічних чинників теми «житло/нерухомість» як соціально-економічної категорії і особливостей іiі відображення у ділових онлайн-медіа України у цьому дослідженні вирішено на прикладі ділового онлайн-медіа «The Page» за допомогою контент-аналізу та контент-моніторингу. Український дослідник Ю. Мосаєв наголошує на напрочуд потужному впливі ділових мас-медіа на громадську думку, розглядаючи процес функціонування ділових медіа та процес їх соціальної спрямованості, відстежуючи особливості висвітлення вектора подання тих чи інших соціально-економічних явищ у медіа [3]. Науковець стверджує, що «ці видання спеціалізуються на інформації, яка $є$ затребуваною у національної економічної та політичної еліти. Здебільшого саме ділові медіа формують громадську думку про більшість соціально-економічних явищ, які є наявними в Україні» [3, с. 108]. Дослідниця Т. Фролова виокремлює чотири основних сфери суспільства: політичну, економічну, соціальну, духовну. Соціальна сфера «визначає предметну своєрідність соціальної журналістики, передусім іiї тематичні особливості: проблеми праці, зайнятості, доходів, освіти, охорони здоров'я, соціального захисту, міжнаціональних взаємин, жінок, дітей сім'ї, інших соціальних груп та окремих 
сегментів, соціальної інфраструктури і т. д. Проблематика більш рухома, мінлива, злободенніша: кожне суспільство вирішує свої власні проблеми, що випливають із характеру соціальних зв'язків у певний історичний період» [4, с. 93]. Натомість К. Шендеровський визначає соціальну журналістику як інтеграцію і взаємозв'язок соціальної роботи i медіадільяності. Ключовим елементом цього напрямку є «сфера вирішення соціальних проблем» $[8$, с. 123]. Аналіз контенту ділового онлайн-медіа «The Page» за 2019-2020 pр. показав, що соціально-економічна тема «житло/нерухомість» реалізується у контексті низки проблемних питань, а саме: проблема доступного житла, комфортного середовища існування/універсального дизайну, житла в контексті прав людини, людиноцентристський підхід до теми житла, економічні складові теми «житло/нерухомість» і питання соціальної відповідальності девелоперів перед покупцями. Варто відзначити, що аналізоване в нашому дослідженні ділове онлайн-видання в 12 авторських журналістських матеріалах із 64 протягом кожного місяця представляє соціальноекономічну тему «житло/нерухомість» у тому чи іншому ключі. Це 19\% від загальної кількості авторських матеріалів. Тема житла посідає третє місце в ієрархії тем економічної проблематики видання: малий та середній бізнес (33,7\%), економіка та фінанси (27,3\%), нерухомість (19) та інше - 20\%. В категорію «інше» потрапляють автомобільна проблематика, енергетичний комплекс, телекомунікації та IT. Своїми матеріалами про соціально-економічну тему «житло/нерухомість» журналісти «The Page» сприяють початку національного діалогу стосовно вирішення питань економічних і політичних перетворень в сфері нерухомості, зменшення безробіття та недоступності категорії житла. Завдання ділового медіа у контексті висвітлення соціально-економічної проблематики концепту «житло/нерухомість» можна сформувати наступним чином:

1. Всебічне інформування суспільства про соціальну і економічну складову житла;

2. Поширення достовірної інформації про стан, тенденції та перспективу ринку нерухомості в контексті вирішення низки соціальних питань;

3. Сприяння публічній звітності органів державної влади стосовно реалізації основоположних засад державної житлової політики;

4. Висвітлення і сприяння подоланню окремих соціальних проблем - недоступності житла, відсутності комфорту, затишку, безпеки.

Зауважимо, що від засобів масової інформації різного типу залежить представлення соціально-економічної теми «житло/нерухомість» в масовій свідомості громадян. Недостатня увага медіа може стати причиною гальмування вирішення окреслених раніше проблем ринку нерухомості, його розвитку і становлення. Моніторинг публікацій 
ділового онлайн-медіа - підтвердив актуальність та соціальну значущість досліджуваного концепту та дав виокремити найтиповіші теми в матеріалах журналістів: доступність житла, доступність фінансових інструментів покупки, комфортність/людиноцентричність, актуальні питання правозахисту в сфері нерухомості, інклюзивність та універсальний дизайн як підходи до розуміння соціальної складової категорії «житло/нерухомість».

Метод контент-аналізу використано з метою підтвердження наукової гіпотези: соціально-економічна тема «житло/нерухомість» є складною синтетичною категорією, яка стосується економічного і соціального життя суспільства, і має бути представлена у медіа у контексті усіх соціальних і економічних факторів іiі існування. Для отримання результатів щодо якісних та кількісних характеристик реалізації соціальноекономічної теми «житло/нерухомість» в діловому онлайн-медіа «Тhe Page» сформовано методологічні принципи класифікації основних тематичних аспектів досліджуваних матеріалів. Зауважимо, що звернення журналістів до соціально-економічної сфери житла відбувається у контексті економічної проблематики, себто на перший план виходить поняття «нерухомість», «товар», «майно», а вже потім - комфорт, середовище існування, житель тощо. Переважна більшість матеріалів у виданні представлені в синтетичних жанрах - авторська колонка, журналістське розслідування, фічер, нарис, аналітична стаття. Аналіз контенту видання показав, що соціально-економічна тема «житло/нерухомість» реалізується у контексті низки проблемних питань, а саме: проблема доступного житла, комфортного середовища існування/універсального дизайну, житла в контексті прав людини, людиноцентристський підхід до теми житла, економічні складові теми «житло/нерухомість» і питання соціальної відповідальності девелоперів перед покупцями.

\section{Література:}

1. Друль Н. Висвітлення причин фінансової кризи на сторінках якісних періодичних видань Свропи - «Тhe economist» (Велика Британія) та «Коммерсантъ» (Росія). Вісник Львівського університету. Серія «Журналістика». 2011. Вип. 35. С. 262-269.

2. Луценко О. Сучасна модель спеціалізованих видань з проблем економіки. Вісник Львівського університету. Серія «Журналістика». 2007. Вип. 30. С. 214-221.

3. Мосаєв Ю. В. Особливості відображення соціально-економічних проблем сучасності в ділових засобах масової інформації. Вісник Львівського університету. Серія соиіологічна. 2012. Вип. 6. С. 108-114.

4. Фролова Т. И. Социальная проблематика / Проблематика СМИ : Информационная повестка дня : учеб. пособ. для студ вузов / под. ред. 
М. В. Шкондина, Г. С. Вычуба, Т. И. Фроловой. М. : Аспект Пресс, 2008. С. $98-142$.

5. Холод О. М. Соціальні комунікації: соціо- та психолінгвістичний аналіз : навч. посіб. Львів : ПАІС, 2011. 288 с.

6. Шендеровський К. Моніторинг соціальної роботи. К. : Главник, 2006. $144 \mathrm{c}$.

7. Шендеровський К. Профілактична соціальна робота: теорія i практика. К. : Главник, 2007. 144 с.

8. Шендеровський К. С. Передумови інституалізації соціально значимих медіа. Ученые записки Таврического национального университета им. В. И. Вернадского. Сер. "Филология. Социальные коммуникациu». 2011. T. 24 (63). № 4. Ч. 1. С. 121-134. 